\title{
Defense Policy and Reforms in Bulgaria since the End of the Cold War: A Critical Analysis
}

\author{
Georgi Tzvetkov ${ }^{*}$
}

\section{Introduction}

After the disintegration of the communist system in Eastern Europe the former communist countries had to make an unprecedented transition to a "normal" society. Having been diverted from their natural path of development, with limited private property and political rights, these countries had to once again begin following the European path of development.

Transforming the defense sectors in these societies was a crucial challenge. Yet there were complications in the sphere of defense transformation because of the overlapping of three transitions. The first was the shift from armies established as support for the communist regime to professional military organizations subject to civilian control. ${ }^{1}$ The second was the transition from mass conventional armies that were established to fight in World War III, which was never waged, to militaries that were relatively limited in their number of troops, the main purpose of which is to participate in a broad spectrum of operations beyond national boundaries. The third transition was that from a reliance on large quantities of Soviet equipment - most of it relatively cheap and easy to produce and maintain - to advanced, high-quality (and expensive) Western equipment. These transitions took place in a context of economic crises (of different magnitude) caused by the clash between planned economies and free market realities, when there were still groups in society that were not willing to give up the communist system easily.

Bulgaria was one of the states that faced the steepest challenges. The supporters of the communist regime were many and they were strong. There were, however, objective limitations to Bulgaria's transition as well - the economy was not competitive enough, and the country had to cope with the burden of significant loans. In the military sphere, an additional challenge was what many considered as Bulgaria's "natural" distrust for Turkey, along with strong pro-Russian affiliations.

Despite that, Bulgaria has become part of the European Union, and its armed forces are constantly increasing their preparedness to operate jointly with the armies of NATO and the EU member states. Even though Bulgaria is not the best example of how defense transformation should be carried out, its experience can be a valuable source of lessons for other states facing similar challenges.

* Georgi Tzvetkov is an Assistant Professor at "G.S. Rakovski" National Defense Academy, Sofia, Bulgaria, and works on a PhD dissertation on Shaping Bulgaria's Defense Policy (1990-2010). He holds a BA in political science from Sofia University (2007) and masters degrees in National Security and Defense (National Defense Academy, 2008) and in Political Management (Sofia University, 2009).

1 Samuel Huntington, The Soldier and the State (Sofia: Military Publishing House, 1998), 8486. 


\section{Conceptual Foundations}

The policy of a state is a sequence of consecutive, interconnected actions, the aim of which is to achieve a certain goal. In terms of defense policy, however, one has to examine the following considerations:

1. Defense policy is the policy of a state with regard to the development and use of its armed forces in order for the national interests to be achieved. The end goal is to achieve readiness for the military to be used (and to use force, if necessary) in order to achieve specific national goals.

2. A decision to deploy the armed forces in conflict situations is expected to be in line with defense policy, but once it has been made, it is understood that the conflict will evolve according to specific principles and circumstances. ${ }^{2}$

3. In that sense, the main focus of defense policy is to establish, maintain, and develop a defense capability - that is, particular armed forces capabilities and the capabilities supporting the military. ${ }^{3}$ The participation in military operations (in terms of military "performance" on the battlefield) is only one of the indicators for the efficiency and effectiveness of defense policy.

Therefore, defense policy consists primarily of defense management, but it also includes civil-military relations and the creation of the framework of military operations. Decisions related to the defining of national security interests, international relations, participation in alliances, and the launching of (or participation in) military operations are beyond the scope of defense policy. The conducting of military operations is also a separate, almost entirely military field of action, because once a decision about participation in a conflict is made the military operation develops in compliance with its own rules. 4

Defense policy should answer the following questions: What is the desired force model necessary to achieve the national interests? How should the available resources be managed as efficiently as possible to develop and sustain the required capabilities? How is the defense acquisition process to be organized in order to procure equipment needed to achieve the required capabilities at the best price throughout the life cycle of given systems?

In terms of civil-military relations, defense policy should establish a model that protects military professionalism and provides effective democratic control over the armed

2 Assuming that participation in a conflict is always an expression of willingness (i.e., it is voluntary).

3 Hari Bucur-Marcu, Philipp Fluri, and Todor Tagarev, eds., Defence Management: An Introduction (Geneva: Geneva Centre for the Democratic Control of Armed Forces, 2009); available at http://www.dcaf.ch/Publications/Defence-Management.

4 See Carl von Clausewitz, On War (first published in 1832; available in translation at www.clausewitz.com): "That the tendencies and views of policy shall not be incompatible with these means, the art of war in general and the commander in each particular case may demand, and this claim is truly not a trifling one." 
forces. As to the launching of military operations, defense policy should ensure that the political goals are adequate to the military capabilities and that the armed forces will not face unrealistic tasks. ${ }^{5}$

Defense policy comprises the following main elements: ${ }^{6}$

- Strategic guidance: Long-term analysis of possible future conflicts (or nonconflict situations) where the armed forces could be used. At this stage the type of future operations that the capabilities of the armed forces are to be established for have to be stipulated.

- Force planning: Stipulating the specific military capabilities that the armed forces are to have in order to be able to perform the tasks set for them within the framework of the expectations for future conflicts.

- Resource management: Making key decisions about how to manage available human, financial, material, etc., resources in the most efficient way possible in order for the necessary defense capabilities to be acquired, maintained, and developed.

- Acquisition: The management of major investments in defense. Since the price of military systems is very high, they are connected with huge costs throughout their whole life cycle and they bind the state for decades to come. Thus, making the correct investment decisions is an activity of supreme importance.

In order to analyze a country's defense policy, the following evaluation criteria are going to be used:

1. Strategic thinking: The maintaining and development of the military capacity needed to protect the national interests can be performed in an efficient way only if this is part of the overall vision for the development of the nation. Very important issues such as the amount of defense costs, the obligations of the citizens and civil society in terms of the armed forces, the coordination with other state bodies in terms of the domestic role of the army (providing support to the public authorities), etc., directly depend on the existence of a strategic national vision.

2. Adequacy: Stipulating national defense capabilities that are adequate to the overall national security policy. It is assumed that the national security policy is

5 Ibid. "Thus, therefore, the political object, as the original motive of the war, will be the standard for determining both the aim of the military force, and also the amount of effort to be made. And now, the first, the grandest, and most decisive act of judgment which the statesman and general exercises is rightly to understand in this respect the war in which he engages, not to take it for something, or to wish to make of it something which, by the nature of its relations, it is impossible for it to be."

6 These main elements are based on Todor Tagarev, "Concept for Strategic Defense Management," IT4SecReports 46 (Sofia: IICT, 2010); and Todor Tagarev, "The Art of Shaping Defense Policy: Scope, Components, Relationships (but no algorithms)," Connections: The Quarterly Journal 5:1 (Spring-Summer 2006): 15-34. 
adequate to the security environment in terms of selecting the course of action in order for full range of different national interests to be achieved.

3. Feasibility: The requirements set for the armed forces have to correspond to the preparedness of the state to allocate the resources necessary to them. It is necessary for the balance between ambitions and capabilities to be established first.

4. Flexibility: The maintenance and development of armed forces capabilities is a long-term process, and with long-term forecasts and planning it is certain that they will come true only partially. In that sense the decisions made about capabilities development have to allow for adjustments in case of changes in the environment (including new threats, reductions in funding, falling behind in terms of deadlines, etc.). ${ }^{7}$ These considerations must include negative changes as well as new opportunities.

5. Determination: Decision making should be followed by actions in the required direction. Often, however, the decisions made are not followed by actions-because of resistance, high cost, public discontent, etc. Determination is showing the will to apply in practice the decisions that have been made, irrespective of the fact that they may contradict the interests of some groups in society.

6. Continuity: A state (public) policy usually designates the policy of a certain government. In the democratic system competing parties put forward competing policies, which are more beneficial to some parts of society than to others. But in the case of defense policy, the decisions made refer to the whole state, and not to individual groups within society. ${ }^{8}$ Moreover, in most cases defense capabilities development requires actions, the duration of which exceeds a single term in office.

\section{The Starting Point: The Bulgarian People's Army in 1989}

The Bulgarian People's Army (BNA) had level of saturation of armament and equipment that was unprecedented in Bulgarian history, and its peacetime personnel amounted to more than 100,000 people. ${ }^{9}$ It played an important role in the plans of the Warsaw Treaty Organization in terms of the southern strategic theater. In the middle of the 1980s, however, serious issues came to the fore. First, overall the countries from the Eastern Bloc lagged behind their Western rivals from a technological perspective. ${ }^{10}$ Second, Bulgaria had issues with an insufficient number of conscript soldiers due to its ag-

7 Henry C. Bartlett, “Approaches to Force Planning," in Fundamentals of Force Planning (Newport, RI: Naval War College Press, 1990), 326-30.

8 Todor Tanev, Analiz na publichnite politiki (Public Policy Analysis) (Sofia, Military Publishing House, 2008), 35, 51.

9 Atanas Semerdzhiev, Prezhivianoto ne podlezhi na obzhalvane (Sofia, Hristo Botev Publishing House, 1999), 269.

10 Ibid., 237-42. 
ing population (a reduction of 10 percent in the number of available military-age men had been foreseen by the mid-1990s ${ }^{11}$ ). In that respect, the fact that the force structure was too rank-heavy was taken into account. By 1990 it was already clear that it would be very difficult to provide funds for the next stage of technological rearmament. ${ }^{12}$

The BNA was one of the main pillars of the communist regime in the country. When talking about military professionalism, Samuel Huntington calls the period of the Third Reich "Civilianism Triumphant," 13 and describes the gradual takeover of the German military by the political leadership and in particular by Adolf Hitler and the NationalSocialist Party. ${ }^{14}$ Even this example is not sufficiently strong to describe the level of political control over the armies in the communist states and the indoctrination of the officer corps in communist ideas through the powerful GPU (Head Political Office) and the political deputy commanders.

Despite the fact that throughout the communist regime Bulgaria's Ministers of Defense (War) were representatives of "the military," in fact the last two professional military men who had occupied that position were General I. Marinov (in 1944) and General Y. Mutafchiev (from November 1990 to November 1991). Two general/ ministers (those in office from September 1944 through 1946) were among the direct organizers of the coup of 9 September 1944, which led to the establishment of the communist dictatorship. Three general/ministers (in office from October 1946 until March 1962) were political emigrants to the USSR after the events of 1923, and became officers first in the Soviet Army (the Workers' and Peasants' Red Army, or RKKA). Bulgaria's fourth Minister of Defense under the communist regime, General D. Dzhurov (in office from March 1962 until November 1989), who had completed his military education in the USSR, was a guerrilla commander from the circle close to the head of state and head of the party Todor Zhivkov.

The last professional officer to be in charge of the General Staff before General Radniu Minchev (in office from August 1990 until August 1991) was General Raycho Slavkov, who was Defense Minister for three months in 1944 and was shot dead by a firing squad in 1953. Two heads of the General Staff (in office from December 1944 through December 1950) began their career during the events of 1923 and received their first officer promotion in the Soviet Army, and another four, including the one with the longest term in office-Atanas Semerdzhiev, who served from March 1962 through December1989-received their first officer promotions in the guerrilla squads during World War II. A significant portion of the high-ranking officers in the officer corps did not have professional but rather "anti-fascist" backgrounds. ${ }^{15}$

It is also important to point out the role of the Bulgarian People's Army in the country's security architecture. The BNA was in fact established as a branch of the RKKA, with the direct participation of Bulgarian political emigrants (Soviet officers) and Rus-

\footnotetext{
Ibid., 268-69

Ibid., 269-70.

Huntington, The Soldier and the State, 98-118.

Ibid., 109-17.

Semerdzhiev, Prezhivianoto ne podlezhi na obzhalvane, 264.
} 
sian officers. In light of this fact, one can only speculate about the capabilities of the BNA to guarantee the "national" security of the country. The national security of the People's Republic of Bulgaria was perceived only within the framework of the communist community in general, and through the lens of military cooperation with the USSR in particular. One should not forget that in view of the Cold War the meaning of the term "guaranteeing national security," especially in the case of small states on the borders of the opposed blocs, such as Bulgaria, was very unclear. Undoubtedly the high-ranking military leadership by the end of 1989 identified itself with the communist ideology and the Bulgarian Communist Party. The perception of national security was limited to maintaining the right balance of forces in relation to Bulgaria's neighbors from the "other camp," namely Turkey and Greece.

\section{The Evolution of Bulgarian Defense Policy}

\section{Where Do We Go without the USSR and the Organization of the Warsaw Treaty? (1990-92)}

With the ever-growing distance in time, it is now clear that the communist system in Eastern Europe collapsed between 1989 and 1991. Back then, however, it did not appear to be the case. The high-ranking military leaders, who were then professional military men (unlike the guerrilla generals) but were still strongly connected to the communist regime, were trying to preserve the status quo as much as possible. Even after the disintegration of the USSR there were hopes that Russia would be able to "keep" at least some of its positions; in the worst-case scenario a common security system would be established in Europe that would preserve Russian influence, and it would partially neutralize the United States. ${ }^{16}$ The "reform" actions that were undertaken had to do mainly with the replacement of symbols and abolition of the political structures in the army (the former political officers acquired "new qualifications").

\section{Who Will Control the Army? Development at a Standstill (1992-97)}

The democratic forces that came to power wanted radical reforms, but they lacked professionalism. Replacing some of the old military leaders and establishing civilian control over the armed forces, which were still seen as a potential threat to democracy, was the main focus of their actions. There was no real understanding of "defense policy." Very few steps were taken in the direction of a transformation of the capabilities of the armed forces for a new type of warfare. There was a perception that the army was established

16 During a press conference by the Minister of People's Defense on 14 November 1990, when answering a question about the prospect of Bulgaria's membership in NATO, General Mutafchiev said: "Bloc structures are an anachronism in international relations and now we must try to find [an]other national security system." Yordan Mutafchiev, Na glavnoto napravlenie (Sofia: Media Print, 2010), 485-87. In an interview with Vecherni Novini on 29 January 1991, the Minister said that Bulgaria still had military guarantees from the USSR (Ibid., 496). 
on the basis of an outdated concept, that there were too many officers, ${ }^{17}$ and that the combat capability of the army was decreasing as a result of the lack of modernization and reduced training, but overall there was little will for a real transformation to begin. The serious issues in society and the economy helped preserve the status quo, and the pressing issues facing the army were shelved. The conflicts in the region also supported the idea that still held sway within the military establishment about preserving the Cold War army structure and putting off real reforms. It might seem like a paradox now, but at that time the fact that the military organization was transformed from an "aggressive" army-divisional structure to a "defensive" corps-brigade structure was seen as sufficient to meet NATO requirements and considered to be a major achievement of the reform. ${ }^{18}$

The position of the high-ranking military leadership enjoyed the support of the Bulgarian Socialist Party and President Zhelev (who had been nominated for president by the Union of Democratic Forces). Their joint position was "Leave the military alone. They know what they are doing." ${ }^{19}$ As a result, as of 1993 any attempts at making reforms that would have jeopardized the interests of the military establishment died out. The obvious conflict of interests and the preference of the military establishment for a large standing army, even though there was not sufficient funding for it, were not taken into account.

\section{The Beginning of the Real Reforms: Preparation for NATO Membership (1997- 2004)}

The financial crisis of 1996-97 finally launched the defense sector reforms that had been long delayed. The failed attempt for some form of "restoration" or at least "preservation" of elements of the communist regime was a powerful tool in the hands of the pro-reform forces. Claiming, however, that there was no alternative available other than NATO membership and that there was a national consensus on the issue is too farfetched. On several occasions of critical importance - the adoption of the National Security Strategy and the Military Doctrine, and the decision to give NATO forces access to Bulgarian air space for attacks on Yugoslavia, for example - the opposition (the former Communist Party) was firmly opposed. ${ }^{20}$ In the absence of any sufficiently good "Eastern" integration project, the opposition put forward ideas about NATO being "archaic," about a "balanced policy," "neutrality," the importance of being "equally distanced from Russia and NATO," etc.

17 There were 22,000 officers in a total army strength of 111,000 in 1992. See Nikola Daskalov, Slavnoto vreme (Sofia, Ciela, 2012), 344.

18 Todor Tagarev, Phases and Challenges of Security Sector Reform in the Experience of Bulgaria, IT4Sec Reports 85 (Sofia, June 2011).

19 The ex-Deputy Minister of Defense in the UDF-led Government of Filip Dimitrov in 1992, Nikola Daskalov, wrote that in the relations of the MoD with the General Staff, the President supported the ambitious Chief of the General Staff (General L. Petrov) in his struggle with the "civilians." See Daskalov, Slavnoto vreme, 348-401.

20 These positions were clearly stated in parliamentary debates, the minutes of which can be found at http://www.parliament.bg/bg/plenaryst. 
In this period, and especially during the Kosovo crisis, opponents of the reforms came up with the thesis that the reforms were untimely, because the country was threatened by the possibility that the conflict would spread. ${ }^{21}$ Overall they did not accept the position that a bigger army, with the limited human, financial, and material resources it would have, was in fact less combat capable than the smaller army that was being proposed by the government. In fact the unambiguous study of the expert group from USEUCOM, led by Major General Kievenaar (1999), concluded that in the Bulgarian Army, with 112,000 military personnel, there was not a single formation at a brigade or a higher level that was fully combat capable. ${ }^{22}$

Since the military leadership already held the perception that the army would be "protected" from encroachments from the "outside" (often seen as intentional actions of "politicians," dictated from abroad), ${ }^{23}$ the Council of Ministers and the Ministry of Defense $(\mathrm{MoD})$ had to use foreign military expertise to achieve reforms in the army. ${ }^{24}$ What was strange was that the Bulgarian military establishment accepted the anachronism of a mass army, prepared for a large-scale conflict with a Western foe, but they were incapable of offering a well-grounded (including from a financial perspective) model of a contemporary Western type of army. The trend for objecting to the acquisition of "Western" armament was still strong. The option that was finally adopted preserved the capabilities of a full-mobilization army (but only temporarily, since its rearmament with "Western" equipment was absurd), but Rapid Reaction Forces were established, which were to turn into the backbone of the army and be interoperable with NATO. $^{25}$

21 It may be surprising, but even the first "democratic" Defense Minister, Dimitar Ludzhev, supported that position during the plenary debates on the new Military Doctrine.

22 "The reliance on conscript soldiers has contributed to the observation that there are in effect no combat capable elements in the Land Forces. All Land Forces units are essentially basic training units, continually attempting to train, assimilate, and discharge a steady flow of shortterm soldiers." Bulgarian Defense Reform Study, Office of the Assistant Secretary of Defense for International Security Affairs and USEUCOM (1999), 33. "The Bulgarian Land Forces currently have the capability to conduct extremely limited defensive operations and maneuver warfare within the boundaries of the country." Ibid., 46.

This perception is very clearly visible in the memoirs of General Yordan Mutafchiev (Minister of Defense and Chief of MoD Inspectorate), Na glavnoto napravlenie; General Tzvetan Totomirov (Chief of General Staff), Zhivot po garnizoni (Sofia: Military Publishing House, 2007); LTG Kiril Tsvetkov (Chief of Land Forces HQ), Pod syankata na promenite i pagona (Sofia: Media Nikolova, 2011); and Major General Angel Marin (Chief of Land Forces Artillery and, later, Vice-President), Raport (Sofia: Zahari Stoyanov, 2013).

24 The Kievenaar's group and, later, MPRI experts.

25 "The future force structure envisioned by the Bulgarian Armed Forces is appropriate only if Bulgaria is planning to fight a war in the near future against a significant external conventional threat. Given the degree of the current and future threat perceived in the National Security Strategy and the draft National Military Strategy, a great amount of resources are being depleted in an attempt to gain a combat capability to perform a mission which is assessed as being highly improbable." Bulgarian Defense Reform Study (1999), 28. 
There were two other important factors that influenced the development of the capabilities of the Bulgarian Armed Forces significantly. One of them was the "professionalization" of the army - i.e., the gradual introduction of voluntary military service. This took place mainly because of Bulgaria's integration into NATO, which preceded the nation's accession to full membership, and because of the requirements of expeditionary operations. Apart from the fact that voluntary military service was a new phenomenon (although it was used between the two World Wars), it was not accepted in an unambiguous way, and it faced a number of difficulties while being introduced. The second important factor had to do with Bulgaria's participation in expeditionary operations. The first contingents - consisting of professional officers, NCOs, and contract soldiers from the different army formations (since there was not a single formation that was fully "professional") - coped relatively well in low-intensity operations near the national borders with Bosnia and Herzegovina and Kosovo. The real test was the operation in Iraq.

Despite the overall negative public opinion in Bulgaria regarding the Iraq conflict, the National Assembly made a decision on 29 May 2003 to participate in the operation in Iraq with a battalion, but without some units for combat support (up to 500 soldiers). The expectations were for an operation of low risk and low intensity. Having insufficiently taken into account the experience from Bulgaria's humanitarian mission in Cambodia (1992-93), the battalion was yet again manned ad hoc with volunteers (no conscript soldiers) from different military units, and its overall equipment did not meet the requirements of contemporary warfare. Under these unfavorable conditions, the battalion performed its tasks well, even during the Shia rebellion in Karbala in 2004, although there were casualties, which led to an acute public reaction. Its participation demonstrated that the Bulgarian Army did not have the equipment required to participate in such operations. ${ }^{26}$ Years would have to pass in order for the main deficiencies to be overcome.

The Integration and Modernization that Never Took Place: Where Are the New Capabilities? (2004-13)

In 2004, Bulgaria became a member of NATO. By that time the main stage of downsizing the number of officers and NCOs in the Bulgarian Army had been finalized. The financial resources that became available after the downsizing were to be used for a largescale rearmament program, which would allow the integration of the country into NATO, along with the transformation and integration of its defense industry. ${ }^{27}$

In 2002-04, a Strategic Defense Review was conducted whose aim was to define what the future development of the Bulgarian Army would be, presuming a future strength of 45,000 personnel. The result of this review was the adoption in the spring of

26 Nikolay Slatinsky, Na vnimanieto na gospodin Prezidenta (Sofia: Iztok/Zapad, 2008), 318 19, 400-02; and Ivan Aleksiev, Kerbala, 2004 (Sofia: Military Publishing House, 2013).

27 See, for example, Todor Tagarev, "Prerequisites and Approaches to Force Modernization in a Transition Period," Information \& Security: An International Journal 6 (2001): 30-52; available at http://dx.doi.org/10.11610/isij.0603. 
2005 of a Development and Modernization Plan by 2015. The large-scale plan for transformation anticipated most of the problems that emerged later on:

- It was planned that all soldiers would be contract soldiers (initially to be enforced by 2010, later on changed to 2008). Despite the lower personnel costs in Bulgaria, a fully contract army of 45,000 is a serious budgetary strain. Bearing in mind the fact that Bulgaria's ambitions (which have not yet been realized) for participation in expeditionary operations with up to 1,000 personnel at any time (with rotation), a plan for maintaining 25,000 contract soldiers with 18,000 professional officers and NCOs does not seem entirely well-grounded.

- The army model that was proposed still seemed rank-heavy. ${ }^{28}$

- Neither the planning horizon (ten years) nor the financial resources were sufficient to permit an overall rearmament with Western equipment. Bearing in mind the fact that in the Kievenaar Report of 1999, the modernization horizon given was $2020^{29}$ (i.e., more than 20 years), it is strange that the Development Plan by 2015 aspired to achieve a similar result within a period that is half as long. In addition to that, the modernization projects (amounting to several billions of dollars) had not been prioritized.

Despite the insufficient funding, it has to be pointed out that defense costs by 2009 (BGN 1.34 billion $^{30}$ ) exceeded the forecast of BGN 900 million on which the Kievenaar Report was based ten years earlier. ${ }^{31}$ It is a fact, however, that the funding level of 2.6 percent of GDP by 2015 that had been allowed for was not abolished until the Plan itself was canceled in $2010 .^{32}$ The decision to establish a fully professional army by 2008 exerted additional pressure on Bulgaria's financial resources. Still, in the period from 2004 to 2010, investment costs (which include the acquisition of new armament and equipment, the extension of the life cycle of old systems, as well as investments in infrastructure) exceeded BGN 2 billion $^{33}$ (EUR 1 billion). Projects were implemented for the delivery of multi-role helicopters (Eurocopter AS532 Cougar and AS565 Panther), transport aircraft (Alenia C-27J Spartan), communication equipment, new light and medium wheeled transport vehicles (Mercedes), second-hand frigates (Wielingen class), a minesweeper (Tripartite class), and other specialized equipment.

By 2008-10, however, despite the large programs (for a nation the size of Bulgaria), the issue of why the capabilities of the armed forces had not sufficiently increased came to the fore. The army was still rank-heavy. At the same time, the formations on a tactical level, from the Land and Air Forces as well as the Navy, were still incapable of partici-

\footnotetext{
Slatinsky, Na vnimanieto na gospodin Prezidenta, 483.

Bulgarian Defense Reform Study (1999), 130.

Defense Report 2010 (Sofia, 2011), 12.

Bulgarian Defense Reform Study (1999), 25.

32 Defense Report 2009 (Sofia, 2010), 10. 2.45\% (2005); 2.26\% (2006); 2.5\% (2007); 2.33\% (2008); 2 (2009).

33 On the basis of the annual reports on budget implementation; see www.minfin.bg.
} 
pating in high-risk and high-intensity expeditionary operations. Ten years after the beginning of its defense-sector reforms, Bulgaria still did not have a single combat unit at a battalion/squadron/combat ship level that was fully combat capable according to NATO standards (perhaps with the exception of a light infantry battalion, engineer and logistic modules, and special operation units).

In 2010, Bulgaria conducted a new review of the structures, the results of which were the "White Paper on Defense" and the "Armed Forces Development Plan." Irrespective of the significant progress achieved in terms of the internal reorganization of MoD the significant reduction in the defense budget in the period 2010-13 (down to 1.2-1.4 percent of GDP) postponed the continuation of the modernization process for an undefined period of time. Moreover, since Bulgaria was already a member of NATO and the EU, the national policy focused on unresolved social and economic issues that had turned into priority goals. It is unlikely that in the foreseeable future the country will have the will to restore the levels of defense funding of 2009 or earlier.

\section{What Are We Doing Wrong?}

\section{The Lack of Will and Direction (1990-97)}

It would be difficult to point out any flaws in the defense policy of Bulgaria for the period 1990-97 since, if we applied the definition of defense policy that has already been pointed out at the beginning of this essay, there was no such policy. With the lack of a clear vision about the future development of the state, apart from the fact that the country would be a "democratic" one, the army remained outside the scope of any political or public agenda. The main issue was civil-military relations and doing away with any threat that the army could interfere in the nation's political life (a threat that was intentionally aggravated at a time of acute crisis). In the presence of sufficiently powerful factors (the reformist forces were in power for a little more than a year, in 1991-92, as part of a "minority government") that wanted Bulgaria to remain part of some kind of Eastern integration process or to retain its "neutrality," there was no clear vision about the future development of the army. Defense management, inasmuch as it was at all understood as a concept, was kept firmly within the ambit of the army. Realizing that it was impossible to maintain an army of more than 100,000 personnel, but at the same time lacking any political vision for development, the military leadership tried to preserve at least some of the army's combat capability. Very often, however, some of the high-ranking officers focused their efforts mostly on power struggles between the various services' HQs, the General Staff, the MoD, and the Presidency. ${ }^{34}$

\section{Internal Resistance (1997-2004)}

It was the two governments in the period from 1997 to 2004 that did finally implement a defense policy in the real sense of the concept. The main factor for that was the affirmative commitment to such a policy as well as the relative consensus on Bulgaria's mem-

34 Daskalov, Slavnoto vreme, 388-89; and Mutafchiev, Na glavnoto napravlenie, 353-78. 
bership in NATO. After that, Bulgaria had to reach a condition that would allow it to integrate in NATO structures, which to a large extent predetermined the course of military reform. In this short period of time (two terms in office), the country's defense policy overall corresponded to the criteria that had been established: strategic thinking, adequacy, feasibility, flexibility, continuity, and determination. It has to be pointed out, however, that during this period what the reform effort mainly focused on was the restructuring and downsizing of the armed forces. One can hardly speak of the establishment of new capabilities of the armed forces, and the Bulgarian forces' participation in Iraq proved that. It has to be highlighted, however, that after the serious financial and economic crisis of 1996, even having allocated more than 2.5 percent of GDP to defense, the country could not spend funds on investments in the defense sector. Moreover, the reorganization could not be performed all at once.

A serious factor that impeded reforms was internal resistance from the military establishment. Relying on their political connections - to a lesser extent with President Petar Stoyanov, and to a greater extent with the former leader of the Bulgarian Socialist Party, President Georgi Parvanov, ${ }^{35}$ who had the final say on generals' appointments they tried to counteract on some of the reforms (especially in terms of the number of personnel) and secured the professional promotion of their affiliates. It was in this period that the myth of the "externally" inspired "destruction of the army" was born.

\section{Defense Management Goes Wrong (2004-10)}

After 2004, Bulgaria had the chance to make use of the resources that had become available as a result of the downsizing of the army and to allocate these funds to investments. According to estimates dating back to the end of 1990s, the beginning of a new largescale rearmament program had to be implement after 2004. Something, however, went wrong. The Development Plan by 2015, which was to lead to the integration of the Bulgarian Army with NATO forces, failed to comply with the principles of feasibility and continuity. If until then it had been believed that the "professionalization" of the military had to cover only one part of the Rapid Reaction Forces (three brigades) and certain parts of the Air Force and the Navy, the Development Plan by 2015 stipulated the abolition of conscript military service while keeping the army at a personnel level of 45,000. This was impossible for Bulgaria to accomplish. In addition to that, the lack of a strategic approach and continuity was reflected in yet another decision (made immediately after the new government came to power in 2005), as defense costs were gradually reduced to 1.9 percent of GDP.

The inefficient way the funds allocated to investment costs were used was as important as the unrealistic planning and the overall cutting of costs. With a number of nontransparent deals, which led to reasonable questions and protests, ${ }^{36}$ the available resources were used for acquisitions that succeeded in increasing the capabilities of the

35 Slatinsky, Na vnimanieto na gospodin Prezidenta (Sofia, 2008), 282, 459-61.

36 See https://www.balkanleaks.eu/en/05sofia187.html; and N. Slatinsky, Na vnimanieto na gospodin prezidenta (Sofia, 2008), 77, 450, 482-84, 506-07, 554-55, 586-88. 
armed forces only slightly. The defense management system that was introduced was based on the concepts of capabilities-based planning, program-based budgeting, and life-cycle management. It was, however, only partially operational, which allowed for the concluding of controversial deals. The main institutions having to do with the operation of the army - the National Assembly, the Council of Ministers, and the Presidency - openly or silently supported the deals. ${ }^{37}$

By the end of the period all investment costs were allocated to payments on deals that had already been signed, the costs for personnel and maintenance were on the rise (because of the increase of the standard of living in the country, which was greater than was initially expected), and the overall defense costs were reduced. The steps to review the Development Plan by 2015 that had been made in 2008 were yielding results only partially. It was clear that a new Defense Review was necessary.

\section{Fatigue and Lack of Interest (2010-)}

The financial and economic crisis stimulated the conducting of a new Defense Review, but only partially. What was left was the impression that the primary result that was sought was to make some army resources available in order for them to be allocated to other areas on which the public placed greater priority. In addition to that, the amount of the funding - 1.5 percent of GDP — was low from the perspective of previous Bulgarian experience, and was combined with required maintenance costs for systems that would not receive the level of funding sufficient in order to enable them to reach full combat capability. Yet again there was no strategic thinking. The financial plans of the Ministry of Defense and the Ministry of Finance were different (the Ministry of Finance planned for defense expenditures of 1.2-1.4 percent of GDP). Even the MoD's limited ambitions in the sphere of rearmament were impossible to achieve. The MoD has the determination to overcome the resistance to the personnel cuts, but not to come up with a sufficiently bold solution that could actually be implemented.

\section{Conclusion}

Bulgaria is a good example of the critical need for a strategic vision and governance in defense. It is a fact that in the twenty years after 1990, the country allocated significant funds to defense, bearing in mind what it could afford to spend. However, despite its NATO membership, its participation in expeditionary operations, and the implementation of large-scale investment projects, the Bulgarian Army can hardly be called "fully combat capable." The main reason for this is that for a long period of time (up to 1997) Bulgaria did not have a vision for the implementation of military transformation. When such a vision appeared, there was not enough continuity in order for it to be implemented. There are, of course, issues not only in terms of governance of defense. In the period from 2004 to 2010 there were critical omissions in the functioning of defense management. Bulgaria had a direction to follow (its NATO integration), with serious re-

37 Ibid., 482. 
sources allocated to that goal, but the Ministry of Defense made the mistake of adopting a too-ambitious model of the armed forces, not managing the available resources in a reasonable way, and in the end implementing investment projects that were not sufficiently related to the required combat capabilities. After 2010, the combination of an economic crisis and the loss of trust that the Ministry of Defense could manage its funds well led to a situation in which it would be very unlikely for a large-scale modernization program to be launched soon. Once again, the lack of governance has led to a focus on short-term social issues, whereas defense policy remains outside the scope of interest of the main political powers. 


\section{Bibliography}

Aleksiev, Ivan. Kerbala, 2004. Sofia: Military Publishing House, 2013.

Bartlett, Henry C.. "Approaches to Force Planning." In Fundamentals of Force Planning, 326-30. Newport, RI: Naval War College Press, 1990.

Bulgarian Defense Reform Study. Office of the Assistant Secretary of Defense for International Security Affairs and USEUCOM, 1999.

Daskalov, Nikola. Slavnoto vreme. Sofia: Ciela, 2012.

Defence Management: An Introduction In Security and Defence Management, Edited by Todor Tagarev. Vol. 1., 2009.

Defense Report 2009. Sofia, 2010.

Defense Report 2010. Sofia, 2011.

Huntington, Samuel. The Soldier and the State. Sofia: Military Publishing House, 1998.

Marin, Angel. Raport. Sofia: Zahari Stoyanov, 2013.

Mutafchiev, Yordan. Na glavnoto napravlenie. Sofia: Media Print, 2010.

Semerdzhiev, Atanas. Prezhivianoto ne podlezhi na obzhalvane. Sofia: Hristo Botev Publishing House, 1999.

Slatinsky, Nikolay. Na vnimanieto na gospodin Prezidenta. Sofia: Iztok/Zapad, 2008.

Tagarev, Todor. "Prerequisites and Approaches to Force Modernization in a Transition Period." Information \& Security: An International Journal 6 (2001): 30-52.

Tagarev, Todor. "The Art of Shaping Defense Policy: Scope, Components, Relationships (but no Algorithms)." Connections: The Quarterly Journal 5, no. 1 (2006): 15-34.

Tagarev, Todor. Concept for Strategic Defence Managenment In IT4Sec Reports. Vol. 46. Sofia: Institute of Information and Communication Technologies, 2010.

Tagarev, Todor. Phases and Challenges of Security Sector Reform in the Experience of Bulgaria In IT4Sec Reports. Sofia: Institute of Information and Communication Technologies, 2011.

Tanev, Todor. Analiz na publichnite politiki (Public Policy Analysis). Sofia: Military Publishing House, 2008.

Totomirov, Tzvetan. Zhivot po garnizoni. Sofia: Military Publishing House, 2007.

Tsvetkov, Kiril. Pod syankata na promenite i pagona. Sofia: Media Nikolova, 2011. von Clausewitz, Carl. On War. Project Gutenberg E-Book No. 1946, 2006. 